\title{
Combined Effects of Protocatechuic Acid and 5-Fluorouracil on p53 Gene Expression and Apoptosis in Gastric Adenocarcinoma Cells
}

\section{Gastrik Adenokarsinoma Hücrelerinde Protokateşuik Asit ve 5-Florourasilin p53 Gen Ekspresyonu ve Apoptoz Üzerine Kombine Etkileri}

\author{
(D) Zahra MOTAMEDI 1 , (D) Sayed Asadollah AMINI2, (D) Elham RAEISI ${ }^{3}$, (D) Yves LEMOIGNE4 4 , (D) Esfandiar HEIDARIAN1* \\ 1Shahrekord University of Medical Sciences, Basic Health Sciences Institute, Clinical Biochemistry Research Center, Shahrekord, Iran \\ 2Shahrekord University of Medical Sciences, Basic Health Sciences Institute, Cellular and Molecular Research Center, Shahrekord, Iran \\ 3Shahrekord University of Medical Sciences, Department of Medical Physics and Radiology, School of Allied Medical Sciences, Shahrekord, Iran \\ 4 Institute for Medical Physics, Ambilly, France
}

\section{ABSTRACT}

Objectives: This study evaluated the combined effects of protocatechuic acid (PCA) and 5-fluorouracil (5-FU) on gastric adenocarcinoma (AGS) cells.

Materials and Methods: The 3-(4,5-dimethylthiazol-2-yl)-2,5-diphenyltetrazolium bromide assay, colony formation assay, flow cytometry technique, real-time quantitative polymerase chain reaction, and Western blotting were used to investigate cytotoxic effects, colony formation, apoptosis, $p 53$ gene expression, and Bcl-2 protein level in AGS cells treated with 5-FU and PCA.

Results: Our results demonstrated that PCA $(500 \mu \mathrm{M})$ alone or in combination with 5-FU $(10 \mu \mathrm{M})$ inhibited AGS cell proliferation, inhibited a colony formation, and increased apoptosis compared with untreated control cells. Moreover, the combined 5-FU/PCA exposure led to upregulation of p53 and downregulation of $\mathrm{Bcl}-2$ protein when compared to the untreated control cells.

Conclusion: The results demonstrate that the combined 5-FU/PCA may promote antiproliferative and pro-apoptotic effects with the inhibition of colony formation in AGS cells. The mechanisms by which the combined 5-FU/PCA exposure exerts its effects are associated with upregulation of p53 gene expression and downregulation of $\mathrm{BCl}-2$ level. Therefore, the combination of 5-FU with PCA not only could be a promising approach to potentially reduce the dose requirements of $5-\mathrm{FU}$ but also could promote apoptosis via p53 and Bcl-2 signaling pathways.

Key words: Apoptosis, 5-fluorouracil, protocatechuic acid, gastric cancer, combination, colony formation

ÖZ

Amaç: Bu çalışma protokateşuik asit (PCA) ve 5-florourasilin (5-FU) gastrik adenokarsinoma (AGS) hücreleri üzerine kombine etkisini değerlendirmiştir.

Gereç ve Yöntemler: 3-(4,5-dimetiltiazol-2-il)-2,5-difeniltetrazolium bromid yöntemi, koloni oluşturma yöntemi, akış sitometrisi tekniği, gerçek zamanlı kantitatif polimeraz zincir reaksiyonu ve Western blot yöntemleri 5-FU ve PCA'ya maruz kalan AGS hücrelerinde sitotoksisite, koloni oluşumu, apoptoz, p53 gen ekspresyonu ve $\mathrm{Bcl}-2$ düzeylerini belirlemek için kullanılmıştır.

Bulgular: Sonuçlarımız PCA'nın tek başına $(500 \mu \mathrm{M})$ veya 5 -FU $(10 \mu \mathrm{M})$ ile kombinasyonunun uygulama yapılmamış kontrol hücrelerine göre AGS hücre proliferasyonunu ve koloni oluşturmunu inhibe ettiğini ve apoptozu artırdığını göstermiştir. Ek olarak, uygulama yapılmamış kontrol hücrelerine göre kombine 5-FU/PCA maruziyeti p53 düzeylerini artırmış ve Bcl-2 düzeylerini artırmıștır.

Sonuç: Sonuçlar göstermiştir ki AGS hücrelerinde kombine 5-FU/PCA maruziyeti koloni oluşumunu inhibe ederek antiproliferatif ve pro-apoptotik etkiler başlatabilir. Kombine 5-FU/PCA maruziyetinin etki gösterme mekanizması $p 53$ geninin artması ve Bcl-2 geninin azalması ile ilişkili olabilir.

*Correspondence: E-mail: heidarian46@yahoo.com, heidarian_e@skums.ac.ir, Phone: +98-383-3346721 ORCID-ID: orcid.org/0000-0002-4701-144X

Received: 26.01.2019, Accepted: 14.03.2019

๑Turk J Pharm Sci, Published by Galenos Publishing House. 
Bu nedenle, 5-FU'nun PCA ile birlikte kombinasyonu 5-FU'nun doz rejimlerinin azaltılmasında potansiyel olarak umut verici bir yaklaşım olurken, aynı zamanda p53 ve Bcl-2 sinyalleşme yolaklarıyla apoptozu başlatabilir.

Anahtar kelimeler: Apoptoz, 5-florourasil, protokateșuik asit, mide kanseri, kombinasyon, koloni oluşumu

\section{INTRODUCTION}

Gastric cancer figures worldwide among the major issues faced by health systems due to its incidence and mortality rate. The 5 -year survival rate for this disease is only about $20 \%{ }^{1}$ Gastric cancer's prevalence varies in different geographic regions. ${ }^{2}$ Gastric cancer can be affected by predisposing factors to gastric carcinoma encompassing familial genetic background, smoking, inadequate intake of antioxidants, disproportionate salt intake, and infection by H. pylori. Furthermore, disorders such as gastritis, intestinal metaplasia, dysplasia, paraneoplastic lesions, and chronic atrophic gastritis are among the underlying causes of gastric cancer. ${ }^{2}$

The therapeutic options for gastric carcinoma are primarily surgery, radiotherapy, and chemotherapy. ${ }^{3}$ 5-fluorouracil (5$\mathrm{FU}$ ) is a heterocyclic aromatic anticancer chemical agent that is widely used to handle various cancers by inhibiting the enzyme thymidylate synthase, preventing DNA replication., ${ }^{4,5}$ However, 5-FU has many side effects (diarrhea, stomatitis, emesis, neutropenia, inflammation of the mouth, loss of appetite, low blood cell counts, hair loss, and skin inflammation). ${ }^{6}$ Moreover, administration of 5-FU is frequently limited by dose-limiting toxicities. Interaction of chemotherapy with natural compounds may present a new perspective and an innovative strategy in cancer therapy. Interestingly, herbal compounds in tandem with 5-FU amplify the synergistic effects of administered therapeutics and exert cytotoxic effects specifically in tumor cells. Combined therapy with synergistic effects not only reduces the drug doses and resistance in chemotherapy but also decreases metastasis, raises the efficacy of 5-FU, and induces apoptosis. ${ }^{7}$ Apoptosis in cells is a type of programmed cell death under the control of factors such as $p 53$ gene expression, which is mutated in most cancer cells. This gene plays a crucial role in genome stability, tumor suppression, induction of apoptosis, cell cycle stopping, and aging. ${ }^{8}$ In addition, p53 acts as a transcription factor for pre-apoptotic proteins. ${ }^{9}$

Various experiments have been conducted to discover and use natural compounds for induction of apoptosis in cancer cells. Epidemiological studies have shown that a diet rich in phytochemical compounds is effective in inducing apoptosis in some cancers. ${ }^{1,10}$ Phytochemicals with antioxidant activity can inhibit carcinogenic processes in several models due to the expression of key proteins in signal transduction pathways and induction of apoptosis. ${ }^{11}$ It is also reported that many polyphenols can reduce the adverse effects of chemical therapies. ${ }^{1}$ Protocatechuic acid (PCA), also known as 3,4-dihydroxybenzoic acid, is a herbal phenolic acid mainly present in fruits, vegetables, and nuts and has anti-inflammatory, antibacterial, antihyperglycemic, anticancer, antiulcer, and antispasmodic properties. ${ }^{12-14}$ Therefore, the aim of the present study was to assess the combined effects of 5-FU and PCA on $p 53$ gene expression, colony formation, apoptosis, and $\mathrm{Bcl}-$ 2 signaling protein level in the gastric adenocarcinoma (AGS) cell line.

\section{MATERIALS AND METHODS}

\section{Chemicals and antibodies}

The investigated human AGS cells were procured from the Pasteur Institute (Tehran, Iran). RPMI 1640 medium, trypsin $0.25 \%$, penicillin/streptomycin (pen/strep), and fetal bovine serum (FBS) were supplied by Gibco (Rockville, MD, USA). $\mathrm{Bcl}-2$ and $\beta$-actin primary antibodies were purchased from Elabscience Biotechnology Co. (Wuhan, China). PCA and 3-(4,5-dimethylthiazol-2-yl)-2,5-diphenyltetrazolium bromide (MTT) were obtained from Sigma-Aldrich (St. Louis, MO, USA). 5-FU was purchased from Haupt Pharma (Wolfratshausen GmbH Co, Germany). The Roti ${ }^{\circ}$ ZOL total RNA extraction kit was obtained from Carl Roth GmbH, Germany. The Annexin V-PI staining kit was purchased from BD Bioscience (California, USA). Glyceraldehyde-3-phosphate dehydrogenase (GAPDH) and p53 primers were purchased from Macrogen Company (South Korea). The other reagents used were of analytical grade.

\section{Cell viability assay}

AGS cells were cultured in 96-well plates (5000 cells per well) overnight in RPMI 1640 medium that contained 10\% FBS and $1 \%$ pen $/$ strep at $37^{\circ} \mathrm{C}$ in $98 \%$ humidity with $5 \% \mathrm{CO}_{2}$. Subsequently, the cells were treated with 5-FU $(0-55 \mu \mathrm{M}), \mathrm{PCA}$ $(0-1100 \mu \mathrm{M}$, solution in dimethyl sulfoxide (DMSO) with $0.1 \%$ final concentration), and the combination of 5-FU with PCA $(10 \mu \mathrm{M}$ and $500 \mu \mathrm{M}$, respectively) for $24 \mathrm{~h}$. Then the medium was removed and the cells were incubated with MTT solution $\left(5 \mathrm{mg} / \mathrm{mL}\right.$ ) for $4 \mathrm{~h}$ at $37^{\circ} \mathrm{C}$. Afterwards, DMSO was added to each well of 96-well plates. The absorbance of each well was measured with a microplate reader (Stat Fax-2100, USA) at 490-570 $\mathrm{nm}$. The percentage of cell viability was assessed as follows: viability=A (sample)/A (control)x100. ${ }^{15}$ At least three independent experiments were carried out.

\section{Assessing the synergistic effects of 5-FU and PCA}

The $\mathrm{IC}_{50}$ values of 5-FU and PCA were used to determine synergistic effects between 5-FU and PCA through the combination index $(\mathrm{Cl})$ using the $\mathrm{Cl}$ equation: ${ }^{16} \mathrm{Cl}=\mathrm{A} / \mathrm{A}_{50}+\mathrm{B} / \mathrm{B}_{50}$ ' where $A$ related to $5-F U$ concentration in combination with $B$, and $B$ depicting PCA concentration in combination with $A$. $A_{50}$ is the $I_{50}$ of $5-\mathrm{FU}$ and the $\mathrm{B}_{50}$ is the $I \mathrm{C}_{50}$ of PCA. A Cl value of 1 represents an additive effect, $\mathrm{Cl}\langle 1$ indicates synergism, and $\mathrm{Cl}$ $>1$ represents antagonism. ${ }^{17}$ Therefore, a combination of 5-FU $\left(10 \mu \mathrm{M}, I C_{20}\right)$ and PCA $\left(500 \mu \mathrm{M}, I_{30}\right)$ was used based on the results of the MTT assay. 


\section{Colony formation assay}

For the colony formation assay, AGS cells were cultured in 6 -well plates $\left(3 \times 10^{5}\right.$ cells per well) overnight. The cells were then treated with 5-FU alone $(10 \mu \mathrm{M}), \mathrm{PCA}$ alone $(500 \mu \mathrm{M})$, and the combination of 5-FU and PCA $(10 \mu \mathrm{M}$ and $500 \mu \mathrm{M}$, respectively) and incubated at $37^{\circ} \mathrm{C}$ in an atmosphere of $5 \% \mathrm{CO}_{2}$ for $24 \mathrm{~h}$. Then the medium was removed, while the cell culture medium was changed every 2 days for 14 days. Subsequently, the cells were washed with PBS and fixed with $70 \%$ ethanol and colonies were stained with $0.5 \%$ crystal violet. The number of colonies was counted and plating efficiency (PE) was calculated by the following formula: $\mathrm{PE}=$ (number of colonies/ number of seeded cells) $\times 100$ and surviving fraction (SF) was determined by $\mathrm{SF}=$ (number of colonies/number of seeded cells $x$ PE control) $\times 100 .{ }^{18}$

\section{Apoptosis detection assay}

The percentage of apoptosis and necrosis of cells were determined through flow cytometry using the AnnexinV-FITC Apoptosis Detection Kit (BD Bioscience, Franklin Lakes, NJ, USA). Briefly, AGS cells $\left(2 \times 10^{5}\right.$ per well) were cultured in 6 -well plates and incubated overnight. The cells were treated with 5-FU $(10 \mu \mathrm{M})$ and PCA $(500 \mu \mathrm{M})$ or a combination of 5-FU and PCA (10 $\mu \mathrm{M}$ and $500 \mu \mathrm{M}$, respectively) for $24 \mathrm{~h}$. Then the cells were harvested by trypsinization, washed with PBS, and stained with Annexin $V$ for 20 min according to the manufacture's protocol at room temperature in the dark. ${ }^{19}$ The cells were analyzed using a FACScan system (Becton-Dickinson and Company, San Jose, CA, USA).

\section{Reverse transcription-quantitative polymerase chain reaction} (RT-qPCR)

RT-qPCR was then applied so as to assess the $p 53$ gene expression in AGS cells. In summary, total RNA from each of the untreated control cells, 5-FU $(10 \mu \mathrm{M})$, and PCA $(500 \mu \mathrm{M})$ or the combination of 5-FU and PCA ( $10 \mu \mathrm{M}$ and $500 \mu \mathrm{M}$, respectively) was extracted after $24 \mathrm{~h}$ of treatment using Roti ${ }^{\circledR} \mathrm{ZOL}$ solution according to the manufacturer's instructions. The total mRNA concentration and quality of RNA were evaluated by OD measurements at 260/280 ratio using a Nanodrop 2000 spectrophotometer (Thermo-USA). For cDNA synthesis $1 \mu \mathrm{g}$ of RNA was used with a synthesis kit (Takara Bio Inc., Japan) according to the manufacturer's instructions and stored at $-20^{\circ} \mathrm{C}$ for subsequent use. The procedure of cDNA RT was applied using a Prime Script ${ }^{\mathrm{T}}$ Reagent Kit (Takara Bio Inc., Japan) according to the manufacturer's instructions. Then CDNA was expanded by RT-qPCR using SYBR ${ }^{\circledR}$ Green PCR Master Mix (Takara Bio Inc., Japan) in the presence of specific primers. The sequences of the primers for the reaction were as follows: H-p53-F, forward 5'-CCCATCCTCACCATCATCACAC-3' and reverse 5'-GCACAAACACGCACCTCAAAG3' and H-GAPDH-F, forward 5'ACACCCACTCCTCCACCCTTTG3', and reverse 5'GTCCACCACCCTGTTGCTGTA-3'. The primers were prepared with Oligo 6.0 software (Molecular Biology Insights, Cascade, CO, USA) and confirmed by BLAST (NCBI). The GAPDH gene was used as a reference gene for normalization. Enzyme activation was conducted for $10 \mathrm{~min}$ at $95^{\circ} \mathrm{C}$, followed by 40 cycles of initial denaturation at $95^{\circ} \mathrm{C}$ for $10 \mathrm{~s}$ and annealing/ extension at $62^{\circ} \mathrm{C}$ for $15 \mathrm{~s}$ and melting at $72^{\circ} \mathrm{C}$ for $20 \mathrm{~s}$ in a 3000 Rotor Gene (Corbett, Australia) real-time PCR system. ${ }^{20}$

\section{Western blotting}

The AGS cells were grown in $6-\mathrm{cm}$ dishes at the density of $6 \times 10^{5}$. After $24 \mathrm{~h}$ of treatment, protein extraction were performed for the control, 5-FU $(10 \mu \mathrm{M}), \mathrm{PCA}(500 \mu \mathrm{M})$, and the combination of 5-FU and PCA ( $10 \mu \mathrm{M}$ and $500 \mu \mathrm{M}$, respectively) using RIPA lysis buffer $(50 \mathrm{mM}$ Tris $-\mathrm{HCl}, \mathrm{pH} 8,150 \mathrm{mM} \mathrm{NaCl}$, $1 \%$ Triton $\mathrm{X}-100,1 \mathrm{mmol} / \mathrm{L}$ sodium orthovanadate, $0.5 \%$ sodium deoxycholate, $50 \mathrm{mmol} / \mathrm{L} \mathrm{NaF}, 0.1 \% \mathrm{SDS}, 1 \mathrm{mM}$ EDTA, 0.1\% sodium azide, $1 \mathrm{mmol} / \mathrm{L}$ phenylmethylsulfonyl fluoride, 50 $\mu \mathrm{L}$ of protease, and $250 \mu \mathrm{L}$ of phosphatase inhibitor). ${ }^{21}$ The supernatants were collected and protein concentrations were determined using Bradford's procedure. ${ }^{22}$ The Western blot procedure was described previously ${ }^{21}$ and primary antibodies $\mathrm{Bcl}-2$ and $\beta$-actin were used according to the manufacturer's protocols. $\beta$-actin was determined as an internal control. Then the blots were washed with TBS-Tween buffer 3 times for 10 min and they were incubated with horseradish peroxidaseconjugated secondary antibody at room temperature for 2 $\mathrm{h}$ and washed again as described above. Band intensity was evaluated using chemiluminescent reagents (ECL; Thermo Fisher Scientific, USA) and analyzed using Image J software. ${ }^{20}$

\section{Statistical analysis}

The results of all experiments were expressed as mean \pm standard deviation and the experiments were performed at least three times. SPSS (Version 20, SPSS Inc., Chicago, IL, USA) or GraphPad Prism 6 (Graphpad Software, San Diego, CA, USA) was used to perform the statistical analysis. Kruskal-Wallis analyses were used to assess between-group differences for the MTT assay, clonogenic assay, Annexin $V$ assay, and RTPCR. For expression analysis, the relative levels of quantitative gene expression were calculated by the $2^{-\Delta \Delta C t}$ method and the data were expressed as fold change. Melting curve analysis was performed after amplification to verify product identity. Western blotting was repeated 3 times. $P$ values less than 0.05 were considered statistically significant for the differences between the groups. The $\mathrm{Cl}$ was calculated using experimental CompuSyn software (ComboSyn Inc, Paramus, NJ, USA), and $\mathrm{Cl}<1,=1$, and $>1$ indicated synergism, additive effect, and antagonism, respectively.

\section{RESULTS}

Effects of 5-FU, PCA, and their combination on AGS cell viability

The result of the MTT assay demonstrated that 5-FU, PCA, and their combination can reduce the proliferation of AGS cells after $24 \mathrm{~h}$ (Figure 1). The $\mathrm{IC}_{50}$ values of 5-FU and PCA alone were $40 \mu \mathrm{M}$ and $700 \mu \mathrm{M}$, respectively (Figures $1 \mathrm{~A}$ and $1 \mathrm{~B}$ ). The combination of $5-\mathrm{FU}$ and PCA ( $10 \mu \mathrm{M}$ and $500 \mu \mathrm{M}$, respectively) led to a synergistic $\mathrm{Cl}$ equal to 0.6 with strong effects on AGS cell proliferation (Table 1). Moreover, the number of living cells decreased in the combination of 5-FU with PCA $(10 \mu \mathrm{M}$ and 500 $\mu \mathrm{M}$, respectively) relative to untreated control cells and each agent alone (Figure 1C). 


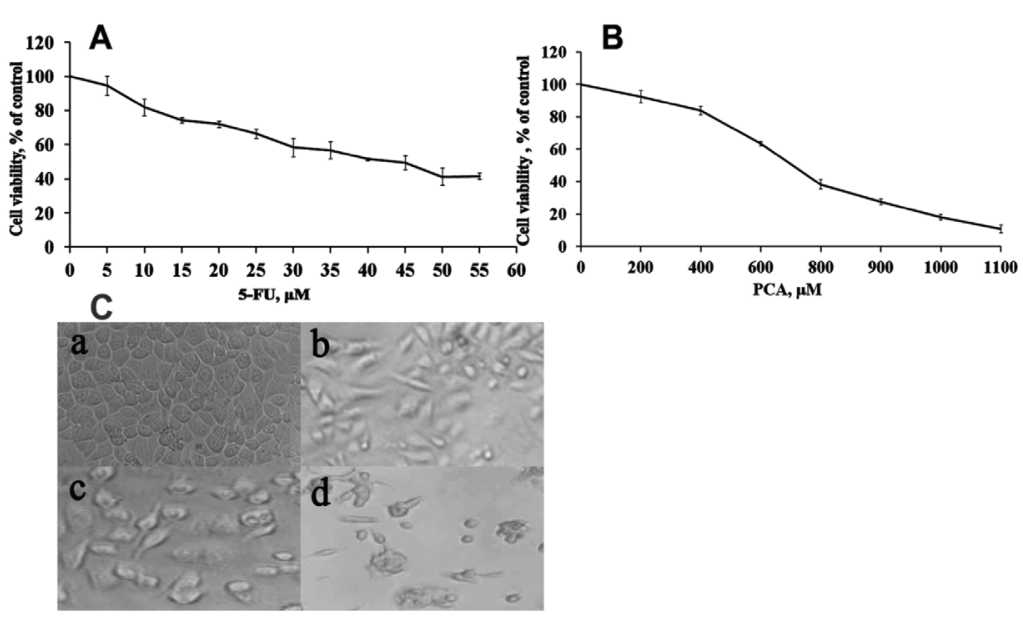

Figure 1. Inhibition of cell proliferation by 5-FU (A) and PCA (B) for $24 \mathrm{~h}$. The cells were cultured at the density of $5 \times 10^{3}$ cells per well for $24 \mathrm{~h}$. At the end of treatment time, cell viability was measured by MTT assay. Data are expressed as mean \pm SD of 3 independent experiments. Also Figure $1 \mathrm{C}$ demonstrates cell morphological changes in AGS cells after treatment with 5-FU, PCA, and their combination. 1C-a: control, 1C-b: 5-FU, 1C-c: PCA, 1C-d: 5-FU plus PCA

5-FU: 5-fluorouracil, PCA: Protocatechuic acid, MTT: 3-(4,5-dimethylthiazol-2-yl)-2,5diphenyltetrazolium bromide, SD: Standard deviation, AGS: Gastric adenocarcinoma

Table 1. The viability percentage of the AGS cell line treated with combination of PCA and 5-FU after $24 \mathrm{~h}$

\begin{tabular}{|c|c|c|c|c|}
\hline \multirow{2}{*}{$\begin{array}{l}\text { Combination } \\
\text { number }\end{array}$} & \multicolumn{2}{|c|}{ Dose combination, micromolar } & \multirow{2}{*}{ Cell viability, \% } & \multirow{2}{*}{$\mathrm{Cl}$} \\
\hline & 5-FU (IC value) & PCA (IC value) & & \\
\hline 1 & $5\left(I C_{10}\right)$ & $600\left(\mathrm{IC}_{40}\right)$ & $39 \pm 4.4$ & 0.72 \\
\hline 2 & $10\left(\mathrm{IC}_{20}\right)$ & $500\left(\mathrm{IC}_{30}\right)$ & $20 \pm 2.7$ & 0.60 \\
\hline 3 & $20\left(\mathrm{IC}_{30}\right)$ & $400\left(I_{20}\right)$ & $45 \pm 4.1$ & 0.81 \\
\hline 4 & $30\left(\mathrm{IC}_{40}\right)$ & $200\left(\mathrm{IC}_{10}\right)$ & $45 \pm 2.9$ & 0.79 \\
\hline
\end{tabular}

AGS: Gastric adenocarcinoma, 5-FU: 5-fluorouracil, IC: Inhibitory concentration, PCA: Protocatechuic acid, Cl: Combination index

\section{Clonogenic assay of AGS cells}

The results of the colony formation assay demonstrated that the combination of 5-FU with PCA ( $10 \mu \mathrm{M}$ and $500 \mu \mathrm{M}$, respectively) significantly decreased the colony numbers of AGS cells and the proliferation rate compared with those of the untreated control cells and 5-FU treated cells (Figure 2). After 14 days of cell culture, the number of colonies consisted of $63,46,30$, and 22 for the control, 5-FU, PCA, and 5-FU/PCA combinations, respectively (Figure $2 \mathrm{~B}$ ). The SF for 5-FU, PCA, and 5-FU/PCA combination were $71 \%, 49 \%$, and $34 \%$, respectively. The results also showed PE in the control and treated experimental cells (Figure 2A).

\section{Effects of 5-FU and PCA on apoptosis}

The results of the flow cytometry showed the percentage of apoptosis and necrosis of 5-FU and PCA in AGS cells (Figure 3). Apoptosis in AGS cells was induced $17 \%$ by $10 \mu \mathrm{M}$ $5-\mathrm{FU}, 23 \%$ by $500 \mu \mathrm{M}$ PCA, and $27 \%$ by the combination of 5-FU and PCA $(10 \mu \mathrm{M}$ and $500 \mu \mathrm{M}$, respectively). Apoptosis significantly increased $(p<0.05)$ in the combination of $5-F U$ and

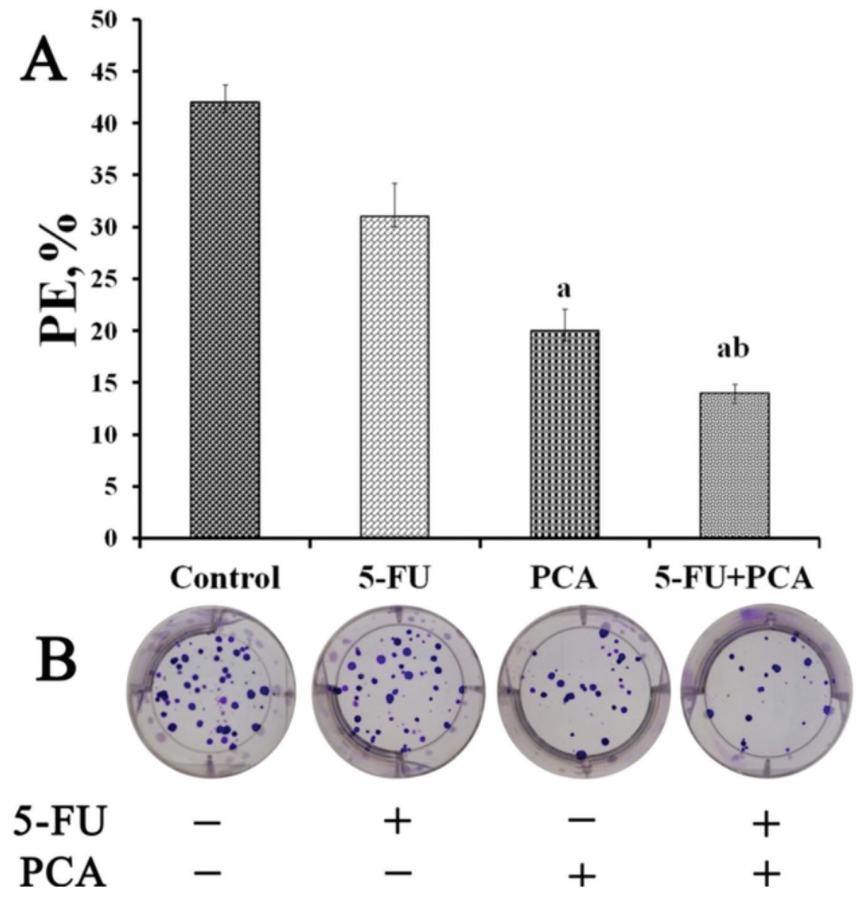

Figure 2. Colonies produced by the AGS cell line in the absence or presence of 5-FU, PCA, and 5-FU/PCA combination. (A): Histogram plot demonstrates plating efficiency (PE) in the control and treated experimental groups. (B): Colony formation in the control, 5-FU, PCA, and combination of 5-FU with PCA

${ }^{a} \mathrm{p}<0.05$ vs. control cells, ${ }^{b} p<0.05$ vs. $5-F U$ treated cells, PE: Plating efficiency, 5-FU: 5-fluorouracil, PCA: Protocatechuic acid, AGS: Gastric adenocarcinoma

PCA treatment when compared to that of the control and 5-FU treated cells (Figure 3).

\section{Expression of p53 in AGS cells}

The results of RT-qPCR showed $p 53$ gene expression in the combination of 5-FU and PCA (10 $\mu \mathrm{M}$ and $500 \mu \mathrm{M}$, respectively). PCA and the 5-FU/PCA combination led to a significant increase ( $p<0.05$ ) in p53 gene expression by almost 5.5- and 11.6- fold, respectively, in comparison with the control cells (Figure 4). No significant change was observed between 5-FU and untreated control cells.

Effects of 5-FU, PCA, and 5-FU/PCA combination on Bcl-2 signaling protein in AGS cells

The result of Western blotting demonstrated that the protein expression level of Bcl-2 markedly decreased after treatment with the 5-FU/PCA combination in AGS cells when compared to that of the untreated control cells and 5-FU treated cells (Figure 5).

\section{DISCUSSION}

The prevalence of cancer is increasing worldwide and the growing rate of mortality is quite alarming. Nowadays, 5-FU-based chemotherapy is a widespread procedure in the treatment of a wide range of cancers, including gastric, colorectal, and breast cancers, due to its effect in the inhibition of thymidylate synthase. ${ }^{23,24}$ Combination therapy not only 

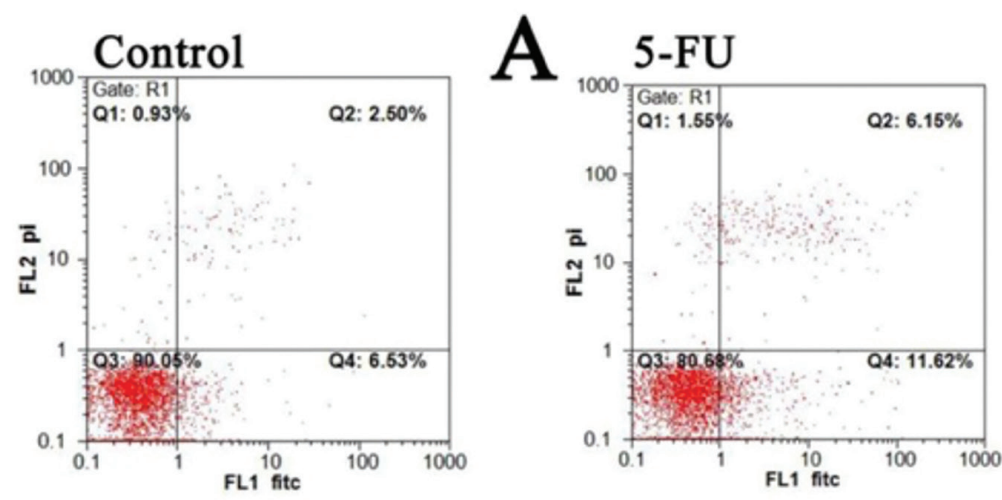

B

PCA
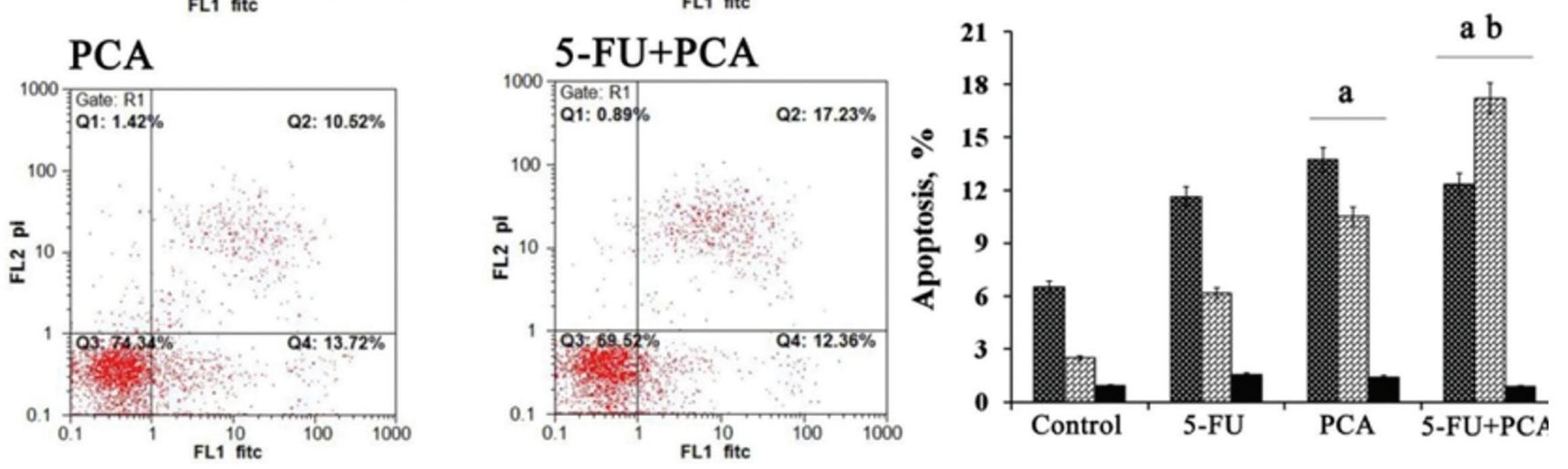

Figure 3. Induction of apoptosis after $24 \mathrm{~h}$ exposure to 5-FU (10 $\mu \mathrm{M})$, PCA (500 $\mu \mathrm{M})$, and combination of 5-FU and PCA (10 $\mu \mathrm{M}$ and $500 \mu \mathrm{M}$, respectively). Data were analyzed by FACScan and represent the mean of duplicate determinations. (A): Flow cytometry charts of Annexin V-FITC/PI staining in untreated (control) AGS cells and cells treated with 5-FU, PCA, and combination of 5-FU and PCA. (B): The percentage of apoptotic AGS cells. The results are expressed as mean $\pm \mathrm{SD}$ of three separate experiments

${ }^{a}$ p $<0.05$ vs. control cells, ${ }^{b}$ < $<0.05$ vs. 5-FU treated cells 5-FU: 5-fluorouracil, PCA: Protocatechuic acid, AGS: Gastric adenocarcinoma, SD: Standard deviation

amplifies chemotherapy's effects on tumor cells at lower concentrations but also it causes little toxicity to normal cells. ${ }^{25}$ In the present study, the combined treatment of 5-FU with PCA had stronger antiproliferation effects than either agent alone (Figure 1). Several previous studies have shown that PCA alone can decrease cell proliferation and viability in some cancer cell lines such as breast, lung, liver, cervix, and prostate cancer cells, ${ }^{26,27}$ which is in line with the findings in the present study. On the other hand, many studies have demonstrated that the combination of natural compounds with chemotherapeutic drugs enhanced their antitumor efficacy through various mechanisms, including cell sensitization, induction of apoptosis, inhibition of cell proliferation, invasion, metastasis, and angiogenesis, ${ }^{28}$ which is in agreement with the findings of our study. It has been reported that natural compounds can disperse vimentin, an epithelial-mesenchymal transition factor, and cause loss of cytoplasmic integrity. These compounds can make changes in cellular morphology through destabilization of the nucleus, cytoskeleton, mitotic spindle, and cell flexibility.,29 Moreover, previous studies have shown that some antioxidants such as curcumin, resveratrol, and epigallocatechin-3-gallate not only have chemopreventive or chemotherapeutic effects but also they act as chemosensitizers on tumor cells.,30-32 Therefore, in the present study it seems that PCA, at least partly, sensitized the AGS tumor cells to 5-FU, which led to increased antiproliferation and cytotoxic efficiency of 5-FU.

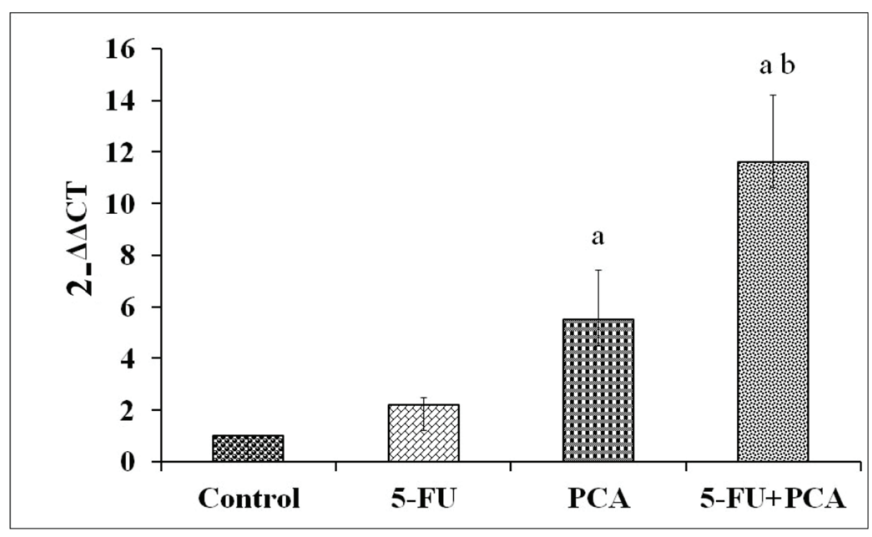

Figure 4. The gene expression of p53 in the presence or absence of 5-FU, PCA, and 5-FU/PCA combination on the AGS cells. Cells were exposed to a combination of 5-FU and PCA $(10 \mu \mathrm{M}$ and $500 \mu \mathrm{M}$, respectively). The expression of $\mathrm{p} 53$ was normalized with GAPDH as an internal standard ${ }^{a} p<0.05$ vs. control cells, ${ }^{b} p<0.05$ vs. 5 -FU treated cells

5-FU: 5-fluorouracil, PCA: Protocatechuic acid, AGS: Gastric adenocarcinoma, GAPDH: Glyceraldehyde-3-phosphate dehydrogenase

Our data demonstrated that the combined 5-FU and PCA resulted in a decrease in the number of colonies when compared to untreated control cells and each agent alone (Figure 2), which was in agreement with previous studies results. ${ }^{33,34}$ A previous study showed that combined 5-FU, cisplatin, and curcumin enhanced the anticancer effects of $5-\mathrm{FU}$ in human 

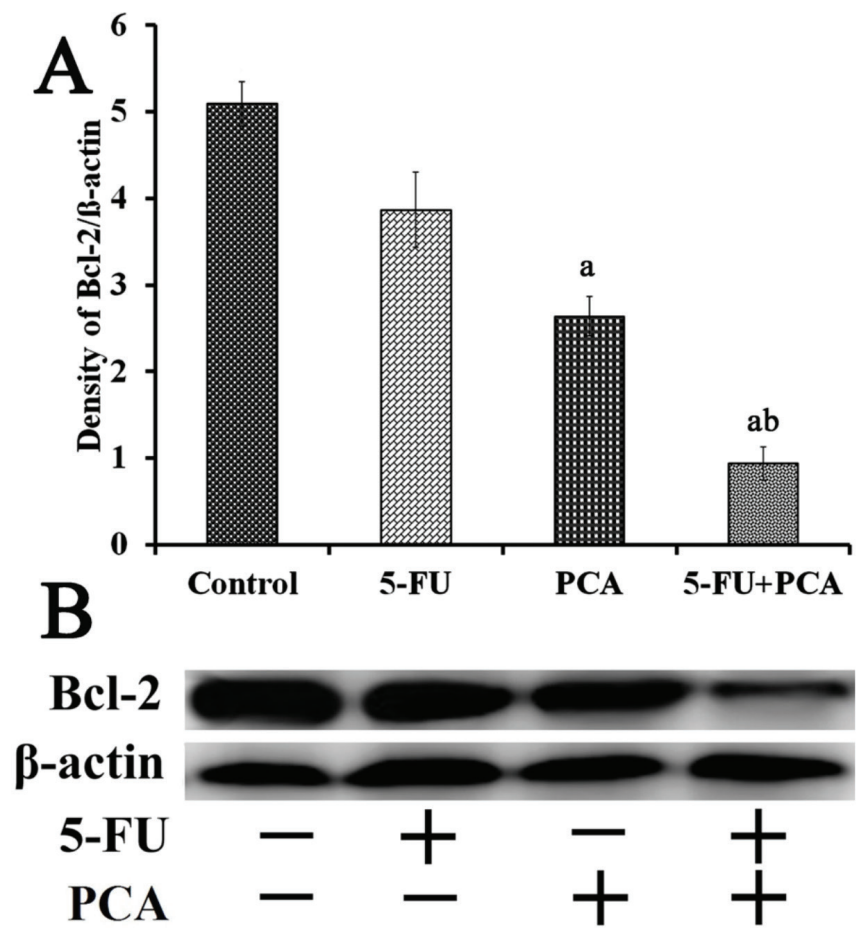

Figure 5. The Bcl-2 level of signaling pathway proteins in the AGS cell line. Cells were treated with 5-FU $(10 \mu \mathrm{M})$, PCA $(500 \mu \mathrm{M})$, and 5-FU/PCA combination (10 $\mu \mathrm{M}$ and $500 \mu \mathrm{M}$, respectively) for $24 \mathrm{~h}$. (A): Density chart of $\mathrm{Bcl}-2 / \beta$-actin and $(\mathrm{B})$ : Western blots bands

${ }^{a} p<0.05$ vs. control cells, ${ }^{b} p<0.05$ vs. 5 -FU treated cells

Bcl-2: Bcl-2 protein 2, AGS: Gastric adenocarcinoma, 5-FU: 5-fluorouracil, PCA: Protocatechuic acid

gastric cancer MGC-803 cells by decreasing cell viability, inhibiting colony formation, and inducing apoptosis, which is in line with the present study findings. ${ }^{33}$ It has also been reported that glabridin, the major isoflavane in licorice root, may inhibit the malignant proliferation of the human gastric cancer MKN45 cell line and enhance the efficiency of 5-FU. ${ }^{34}$ The reduction in the number of colonies in the present study through combined 5-FU and PCA, at least partly, may have resulted from synergistic effects due to loss of sensitized cytoplasmic integrity and cellular changes such as Bcl-2 reduction, p53 elevation, and cell morphology.

Our flow cytometry results demonstrated that treatment with PCA and 5-FU combined resulted in increasing apoptosis in AGS cells compared to the untreated control cells (Figure 3). Antioxidants are used as anticancer compounds and can lead to cell death by activating the internal or external pathways of apoptosis. ${ }^{1}$ It has been demonstrated in several studies that PCA can induce apoptosis in cancer cells, which is in line with the results of the present study. ${ }^{35-37}$ In addition, PCA-induced apoptosis was found to be associated with the inhibition of $\mathrm{Bcl}-2$, the mitochondrial translocation of Bax and Bid, and the cytosolic release of cytochrome $\mathrm{C}$, which is in agreement with our study findings. ${ }^{38}$ On the other hand, it has been found that 5-FU induces apoptosis in cancer cells though p53. ${ }^{24,39-}$ ${ }^{41}$ It has also been reported that administration of $5-\mathrm{FU}$ with troxerutin, a flavonoid, results in a dose-dependent suppression of cell proliferation and induces apoptosis, which is in line with our findings (Figures 1 and 3). ${ }^{42}$ In addition, it is reported that antioxidants can reduce the side effects and potential harmful impact of medications, ${ }^{43}$ influence multidrug resistance genes, which are responsible for resistance to different cytotoxic drugs, and enhance the residence time of chemotherapeutic drugs in cancer cells. ${ }^{7}$ Therefore, in the present study, the elevated efficacy of 5-FU for AGS apoptosis in the presence of PCA, at least partly, is due to PCA antioxidant capacity through sensitized cytoplasmic integrity and cellular changes such as $\mathrm{Bcl}-2$ reduction and $\mathrm{p} 53$ elevation, and can trigger other internal or external signaling pathways of apoptosis.

p53 acts as a transcription factor for a series of pro-apoptotic proteins (such as Bad, Bax, and Bid) and anti-apoptotic Bcl-2 signaling protein and induces apoptosis by releasing cytochrome C. ${ }^{44}$ Natural antioxidants can cause cell death by controlling members of the $\mathrm{Bcl}-2$ family and promoting DNA damage. ${ }^{45}$ In addition, it has been demonstrated that Bcl-2, which encodes an inner mitochondrial protein, can antagonize apoptosis in many tumor cells. ${ }^{38}$ Our results showed that the combined 5-FU/PCA increased p53 gene expression and decreased cellular $\mathrm{Bcl}-2$ signaling protein (Figures 4 and 5). In many previous studies, it was found that PCA has the potential to induce apoptosis, increase p53 gene expression, and cause a decline in Bcl-2 protein, which is in agreement with our findings. ${ }^{38,46}$ Nevertheless, in the present study, it seems that the combination of PCA with 5-FU can strongly increase $p 53$ gene expression (Figure 4). In another study, it was demonstrated that PCA acted as an apoptotic inducer of leukemia by decreasing the phosphorylation of retinoblastoma and decreasing the expression of $\mathrm{Bcl}-2$, which is in line with the present study. ${ }^{38}$ On the other hand, researchers determined that Hibiscus polyphenol-rich extract containing PCA caused apoptosis in human gastric carcinoma cells via p53 phosphorylation and the p38 MAPK/FasL cascade pathway. ${ }^{46}$ In addition, it has been demonstrated that natural antioxidants such as forbesione, lupeol, luteolin, and myricetin can induce synergistic, apoptotic, and antiproliferative effects with 5-FU through the elevation of $p 53$ gene expression and decreasing of the cellular $\mathrm{Bcl}-2$ signaling protein in some cancer cells, which is in line with our findings. ${ }^{47-50}$ Therefore, in the present study, the elevation in p53 gene expression and the reduction in $\mathrm{Bcl}-2$ protein level in the presence of PCA, at least partly, may have resulted from the potential of PCA in cell sensitization to 5-FU by activating intracellular signaling pathways.

In the present study, we did not investigate the effects of the combined 5-FU/PCA treatment on other cellular signaling pathways such as FAK, MAPK, MMP, COX, JNK, Akt, ERK, $\mathrm{Nf- \kappa b,} \mathrm{or} \mathrm{caspases} \mathrm{modulating} \mathrm{factors,} \mathrm{which} \mathrm{influence}$ invasion, metastasis, and apoptosis. We also did not study cell survival factors such as Bcl-xL or cFLIP. Thus, we suggest that prospective researchers investigate the above factors in combined 5-FU/PCA in future studies. 


\section{CONCLUSION}

Our data indicate that the combined 5-FU/PCA treatment may promote antiproliferative and pro-apoptotic effects plus inhibition of colony formation in AGS cells. Some mechanisms by which the combined 5-FU/PCA treatment exerts its effects are associated with the upregulation of p53 and downregulation of $\mathrm{Bcl}-2$ expression. Therefore, the combination of $5-\mathrm{FU}$ with PCA not only could be a promising approach for potential reduction of dose requirements of 5-FU treatment but also could promote apoptosis via p53 and $\mathrm{Bcl}-2$ signaling pathways.

\section{ACKNOWLEDGEMENTS}

We would like to express our gratitude to those who helped us in Clinical Biochemistry Research Center of Shahrekord University of Medical Sciences, Shahrekord, Iran. The results described in this paper were the MS dissertation of Ms. Zahra Motamedi. This study was funded by Shahrekord University of Medical Sciences, Shahrekord, Iran.

Conflicts of interest: No conflict of interest was declared by the authors. The authors alone are responsible for the content and writing of the paper.

\section{REFERENCES}

1. Teng $\mathrm{H}$, Huang $\mathrm{Q}$, Chen L. Inhibition of cell proliferation and triggering of apoptosis by agrimonolide through MAP kinase (ERK and p38) pathways in human gastric cancer AGS cells. Food Funct. 2016;7:46054613.

2. Mohammadi M, Zarghami N, Hedayati M, Ghaemmaghami S. Synergistic effects of resistin and visfatin as adipocyte derived hormones on telomerase gene expression in AGS gastric cancer cell line. Acta Med Iran. 2017;55:621-627.

3. Zheng LC, Yang MD, Kuo CL, Lin CH, Fan MJ, Chou YC, Lu HF, Huang WW, Peng SF, Chung JG. Norcantharidin-induced apoptosis of AGS human gastric cancer cells through reactive oxygen species production, and caspase- and mitochondria-dependent signaling pathways. Anticancer Res. 2016;36:6031-6042.

4. Noordhuis P, Holwerda U, Van der Wilt C, Van Groeningen C, Smid K, Meijer S, Pinedo HM. 5-Fluorouracil incorporation into RNA and DNA in relation to thymidylate synthase inhibition of human colorectal cancers. Ann Oncol. 2004;15:1025-1032.

5. Wagner AD, Grothe W, Haerting J, Kleber G, Grothey A, Fleig WE. Chemotherapy in advanced gastric cancer: a systematic review and metaanalysis based on aggregate data. J Clin Oncol. 2006;24:2903-2909.

6. Hauner K, Maisch P, Retz M. Nebenwirkungen der Chemotherapie. Der Urologe. 2017;56:472-479.

7. de Oliveira Júnior RG, Ferraz CAA, da Silva Almeida JRG, Grougnet $R$, Thiéry V, Picot L. Sensitization of tumor cells to chemotherapy by natural products: a systematic review of preclinical data and molecular mechanisms. Fitoterapia. 2018;21.

8. Sato $\mathrm{Y}$, Tsurumi T. Genome guardian p53 and viral infections. Rev Med Virol. 2013;23:213-220.

9. Jiang L, Sheikh MS, Huang Y. Decision making by p53: life versus death. Mol Cell Pharmacol. 2010;2:69-77.
10. Fresco P, Borges F, Diniz C, Marques M. New insights on the anticancer properties of dietary polyphenols. Med Res Rev. 2006;26:747-766.

11. Sak K. Cytotoxicity of dietary flavonoids on different human cancer types. Pharmacogn Rev. 2014;8:122-146.

12. Tanaka T, Kojima T, Kawamori T, Mori H. Chemoprevention of digestive organs carcinogenesis by natural product protocatechuic acid. Cancer. 1995; 75:1433-1439.

13. Khan AK, Rashid R, Fatima N, Mahmood S, Mir S, Khan S, Jabeen N, Murtaza G. Pharmacological activities of protocatechuic acid. Acta Pol Pharm. 2015;72:643-650.

14. Masella R, Santangelo C, D’archivio M, LiVolti G, Giovannini C, Galvano F. Protocatechuic acid and human disease prevention: biological activities and molecular mechanisms. Curr Med Chem. 2012;19:29012917.

15. Yoshimizu N, Otani Y, Saikawa Y, Kubota T, Yoshida M, Furukawa T, Kumai K, Kameyama K, Fujii M, Yano M, Sato T, Ito A, Kitajima M. Anti-tumour effects of nobiletin, a citrus flavonoid, on gastric cancer include: antiproliferative effects, induction of apoptosis and cell cycle deregulation. Aliment Pharmacol Ther. 2004;1:95-101.

16. Kapp N, Stander XX, Stander BA. Synergistic in vitro effects of combining an antiglycolytic, 3-bromopyruvate, and a bromodomain-4 inhibitor on U937 myeloid leukemia cells. Anticancer Drugs. 2018;29:429-439.

17. Koraneekit A, Limpaiboon T, Sangka A, Boonsiri P, Daduang S, Daduang J. Synergistic effects of cisplatin-caffeic acid induces apoptosis in human cervical cancer cells via the mitochondrial pathways. Oncol Lett. 2018;15:7397-7402.

18. Franken NA, Rodermond HM, Stap J, Haveman J, Van Bree C. Clonogenic assay of cells in vitro. Nat Protoc. 2006;1:2315-2319.

19. Pauzi AZM, Yeap SK, Abu N, Lim KL, Omar AR, Aziz SA, Chow ALT, Subramani T, Tan SG, Alitheen NB. Combination of cisplatin and bromelain exerts synergistic cytotoxic effects against breast cancer cell line MDA-MB-231 in vitro. Chin Med. 2016;11:46.

20. Sun Y, Zhang D, Mao M, Lu Y, Jiao N. Roles of p38 and JNK protein kinase pathways activated by compound cantharidin capsules containing serum on proliferation inhibition and apoptosis of human gastric cancer cell line. Exp Ther Med. 2017;14:1809-1817.

21. Heidarian E, Keloushadi M, Ghatreh-Samani K, Jafari-Dehkordi E. Gallic acid inhibits invasion and reduces $/ L-6$ gene expression, pSTAT3, pERK1/2, and pAKT cellular signaling proteins in human prostate cancer DU-145 cells. Int J Cancer Manag. 2017;10:e9163.

22. Bradford MM. A rapid and sensitive method for the quantitation of microgram quantities of protein utilizing the principle of protein-dye binding. Anal Biochem. 1976;72:248-254

23. Mahlberg R, Lorenzen S, Thuss-Patience P, Heinemann V, Pfeiffer $P$, Mohler M. New perspectives in the treatment of advanced gastric cancer: S-1 as a novel oral 5-FU therapy in combination with cisplatin Chemotherapy. 2017;62:62-70.

24. Longley DB, Harkin DP, Johnston PG. 5-fluorouracil: mechanisms of action and clinical strategies. Nat Rev Cancer. 2003;3:330-338.

25. Sun W, Sanderson PE, Zheng W. Drug combination therapy increases successful drug repositioning. Drug Discov Today. 2016;21:1189-1195.

26. Yin MC, Lin CC, Wu HC, Tsao SM, Hsu CK. Apoptotic effects of protocatechuic acid in human breast, lung, liver, cervix, and prostate cancer cells: potential mechanisms of action. J Agric Food Chem. 2009;57:6468-6473. 
27. Tsao SM, Hsia TC, Yin MC. Protocatechuic acid inhibits lung cancer cells by modulating FAK, MAPK, and NF-kappaB pathways. Nutr Cancer. 2014;66:1331-1341.

28. Shukla S, Mehta A. Anticancer potential of medicinal plants and their phytochemicals: a review. Braz J Bot. 2015;38:199-210.

29. Satelli A, Li S. Vimentin in cancer and its potential as a molecular target for cancer therapy. Cell Mol Life Sci. 2011;68:3033-3046.

30. Hour TC, Chen J, Huang CY, Guan JY, Lu SH, Pu YS. Curcumin enhances cytotoxicity of chemotherapeutic agents in prostate cancer cells by inducing $\mathrm{p} 21 \mathrm{WAF} 1 / \mathrm{CIP1}$ and $\mathrm{C} / \mathrm{EBP} \beta$ expressions and suppressing NFkappaB activation. Prostate. 2002;51:211-218.

31. Fulda S, Debatin KM. Sensitization for anticancer drug-induced apoptosis by the chemopreventive agent resveratrol. Oncogene. 2004;23:6702-6711.

32. Braicu C, Gherman CD, Irimie A, Berindan-Neagoe I. Epigallocatechin3-Gallate (EGCG) inhibits cell proliferation and migratory behaviour of triple negative breast cancer cells. J Nanosci Nanotechnol. 2013;13:632637.

33. He B, Wei W, Liu J, Xu Y, Zhao G. Synergistic anticancer effect of curcumin and chemotherapy regimen FP in human gastric cancer MGC-803 cells. Oncol Lett. 2017;14:3387-3394.

34. Zhang L, Chen H, Wang M, Song X, Ding F, Zhu J, Liu X. Effects of glabridin combined with 5 -fluorouracil on the proliferation and apoptosis of gastric cancer cells. Oncol Lett. 2018;15:7037-7045.

35. Guan S, Jiang B, Bao Y, An L. Protocatechuic acid suppresses MPP+induced mitochondrial dysfunction and apoptotic cell death in PC12 cells. Food Chem Toxicol. 2006;44:1659-1666.

36. Liu YM, Jiang B, Bao YM, An LJ. Protocatechuic acid inhibits apoptosis by mitochondrial dysfunction in rotenone-induced PC12 cells. Toxicol In Vitro. 2008;22:430-437.

37. Lin $\mathrm{HH}$, Chen JH, Huang CC, Wang CJ. Apoptotic effect of 3 , 4-dihydroxybenzoic acid on human gastric carcinoma cells involving JNK/p38 MAPK signaling activation. Int J Cancer. 2007;120:2306-2316.

38. Tseng TH, Kao TW, Chu CY, Chou FP, Lin WL, Wang CJ. Induction of apoptosis by hibiscus protocatechuic acid in human leukemia cells via reduction of retinoblastoma (RB) phosphorylation and $\mathrm{Bcl}-2$ expression. Biochem Pharmacol. 2000;60:307-315.

39. Petak I, Tillman DM, Houghton JA. p53 dependence of Fas induction and acute apoptosis in response to 5-fluorouracil-leucovorin in human colon carcinoma cell lines. Clin Cancer Res. 2000;6:4432-5541.
40. Bunz F, Hwang PM, Torrance C, Waldman T, Zhang Y, Dillehay L, Williams J, Lengauer C, Kinzler KW, Vogelstein B. Disruption of p53 in human cancer cells alters the responses to therapeutic agents. J Clin Invest. 1999;104:263-269.

41. Zhang L, Yu J, Park BH, Kinzler KW, Vogelstein B. Role of BAX in the apoptotic response to anticancer agents. Science. 2000;290:989-992.

42. Xu GY, Tang XJ. Troxerutin (TXN) potentiated 5-Fluorouracil (5Fu) treatment of human gastric cancer through suppressing STAT3/ NF-kappaB and Bcl-2 signaling pathways. Biomed Pharmacother. 2017;92:95-107.

43. Wagner $H$, Ulrich-Merzenich G. Synergy research: approaching a new generation of phytopharmaceuticals. Phytomedicine. 2009;16:97-110.

44. Tiwari M. Apoptosis, angiogenesis and cancer therapies. J Can Res Ther. 2012;1:3.

45. Hussain SA, Sulaiman AA, Balch C, Chauhan H, Alhadidi QM, Tiwari AK. Natural polyphenols in cancer chemoresistance. Nutr Cancer. 2016;68:879-891.

46. Lin HH, Huang HP, Huang CC, Chen JH, Wang CJ. Hibiscus polyphenolrich extract induces apoptosis in human gastric carcinoma cells via p53 phosphorylation and p38 MAPK/FasL cascade pathway. Mol Carcinog. 2005;43:86-99.

47. Boueroy P, Hahnvajanawong C, Boonmars T, Saensa-ard S, Wattanawongdon W, Kongsanthia C, Salao K, Wongwajana S, Anantachoke N, Reutrakul V. Synergistic effect of forbesione from Garcinia hanburyi in combination with 5-Fluorouracil on cholangiocarcinoma. Asian Pac J Cancer Prev. 2017;18:3343-3351.

48. Liu Y, Bi T, Dai W, Wang G, Qian L, Shen G, Gao Q. Lupeol enhances inhibitory effect of 5-fluorouracil on human gastric carcinoma cells. Naunyn Schmiedebergs Arch Pharmacol. 2016;389:477-484.

49. Xu H, Yang T, Liu X, Tian Y, Chen X, Yuan R, Su S, Lin X, Du G. Luteolin synergizes the antitumor effects of 5 -fluorouracil against human hepatocellular carcinoma cells through apoptosis induction and metabolism. Life Sci. 2016;144:138-147.

50. Wang L, Feng J, Chen X, Guo W, Du Y, Wang Y, Zang W, Zhang S, Zhao G. Myricetin enhance chemosensitivity of 5-fluorouracil on esophageal carcinoma in vitro and in vivo. Cancer Cell Int. 2014;14:71. 